DOI: $10.2478 / \mathrm{v} 10025-012-0011-2$

JOURNAL OF WATER

AND LAND DEVELOPMENT

J. Water Land Dev. No. 15, 2011: 115-126

\title{
Productive and economic factors affecting the development of mountain meadow organic farms in the years 2004-2009
}

\author{
Jerzy PROKOPOWICZ, Halina JANKOWSKA-HUFLEJT \\ 1) Institute for Technology and Life Sciences in Falenty, al. Hrabska 3, 05-090 Raszyn, Poland; tel. \\ +48 (22) 720-05-98; e-mail: h.jankowska@itep.edu.pl
}

\begin{abstract}
Studies performed with the method of steered interview were carried out in 2004-2009 in 9 organic meadow farms in mountain areas and in 32 farms in lowland voivodships. The mean area of agricultural lands (AL) in studied farms was 46.14 ha in 2009 and ranged from 3.01 ha to 305.80 ha. Productive (yields and animal stock) and economic (standard gross margin per ha of AL and per fulltime employed person) results were related to natural, agricultural and economic characteristics. A hypothesis was formulated that it is possible to produce ecologically allowable, socially accepted and economically effective healthy food in organic mountain farms.

Analysed factors included: the area of agricultural lands (AL), cow stock, milk efficiency, farmers' age and the value of fixed assets in zł per ha AL. Low to medium level of investment in fixed assets and relatively low level of direct costs of plant and animal production was noted in studied farms. Incomes from agricultural production in studied mountain farms were medium to low; higher from animal (cattle and sheep) than from plant production. Gross margin both per ha AL and per full-time employed person was medium to low in relation to all farms in the country. Generally, the costs of agricultural production in studied organic farms were not always compensated by incomes. They were only compensated by the state and EU subsidies. It was concluded that in both lowland and mountain organic farms the production of high quality food is possible providing a definite level of subsidies.
\end{abstract}

Key words: herd size, cropland structure, employment, meadow organic farm, standard gross margin, subsidies

\section{INTRODUCTION}

Organic farming is the fastest developing branch of agriculture worldwide and particularly in the EU. Products from such farms guarantee healthy food and organic farming is environmental friendly. Consequently, the demand for products from organic farms and their production increases. The number of organic farms increases also in Poland. In 1993 there were 255 such farms (3500 ha AL), in 2002 - 997 farms (53 500 ha AL), in 2007 - 11877 farms (286 thousand ha AL) and in 
2009 - 17138 farms. Their number is expected to increase to 20000 in 2012 and their area - to c. 600 thousand ha (Rolnictwo..., 2009).

Present and future development of organic farming is closely associated with their profitability and competitiveness with other agricultural systems. Decisive in this aspect are obtained yields and their profitability which depend on the production costs (inputs) and on the incomes from sold crops. Comparative analyses of various West European agricultural systems show that the yields are smaller by $10-50 \%$ from those from conventional farms depending on grown plants and the intensity of former conventional farming.

The aim of this study was to analyse productive and economic factors affecting the development of mountain and lowland meadow organic farms. The effectiveness of selected agricultural and economic factors measured with the standard gross margin was related to natural, agricultural and economic characteristics of analysed farms.

Working hypothesis was that it is possible to produce ecologically allowable, socially accepted and economically efficient healthy food in Polish mountain organic farms.

\section{MATERIAL AND METHODS}

Studies were carried out with the method of steered interview in the years 2004-2009 in 9 organic meadow farms in mountain voivodships (małopolskie and podkarpackie) and in 32 farms in lowland voivodships (kujawsko-pomorskie, lubuskie, mazowieckie, podlaskie and pomorskie). The area of AL in both groups of studied farms was 1891.74 ha in 2009 . The area of AL in particular farms ranged from 3.01 ha to 305.80 ha with the mean of 46.14 ha (Źródłowe..., 2004, 2005, 2006, 2007, 2008, 2009).

Farms with animal production based on own grasslands that occupied minimum $30 \%$ of AL were selected for this study. Pollsters were the advisers from the centres of agricultural advisory and main investigators of the project (Badania..., 2005, 2006, 2007, 2008, 2009). The questionnaires included e.g. cropland structure, present stock of farm animals (mainly ruminants), status of machines for harvesting and conservation of grassland fodder, fertilisation, the way and intensity of pasture utilisation.

Farm buildings (without houses) of each farm were described and their type, surface area, current value (in zlotys) and the degree of their utilisation (in \%) were given. Current value was calculated as a difference between the initial value and depreciation estimated by the owner. The equipment of farms with tractors, agricultural machines and tools and the means of farm transport was estimated. Direct costs were calculated for the whole farm and separately for plant and animal pro- 
duction. The costs of fuel, electric energy and hired labour were distinguished from indirect costs.

Standard gross margin (SGM) was adopted as the main criterion for economic assessment of a farm. Standard gross margin is a surplus of three-year mean production value of a given agricultural activity over three-year mean direct costs under average productive conditions for a given region (obtained from a farm, from one ha of croplands or from one animal diminished by direct costs born for this production). Comparison of the revenues with direct costs of farms in the years 2007-2009 gave the standard gross margin "2008” (Metodyka..., 2000).

\section{ECONOMIC AND AGRICULTURAL EFFECTS}

\section{YIELDS OF MAIN PLANT CROPS}

The yields of cereals and potatoes in both groups of organic farms (mountain and lowland) were assessed in relation to the soil quality index of arable lands. Cereal yields were slightly higher (by 13.4\%) in lowland farms (tab. 1) while the yields of potatoes were higher in mountain farms (by 22.5\%) despite lower soil quality index (JANKOWSKA-HUFLEJT et al., 2004). Better agro-technique, for example larger manpower for weed control, contributed mainly to this effect. In general, the yields of field crops do not always correlate with soil quality (measured by the index of soil quality of arable lands).

Table 1. Mean yields of the main plant crops in relation to the index of soil quality in mountain and lowland meadow organic farms in the years 2007-2009

\begin{tabular}{l|c|c|c|c}
\hline \multirow{2}{*}{ Voivodship } & \multirow{2}{*}{$\begin{array}{c}\text { Number } \\
\text { of farms }\end{array}$} & \multirow{2}{*}{$\begin{array}{c}\text { Index } \\
\text { of soil quality }\end{array}$} & \multicolumn{2}{c}{ Yields, t per ha } \\
\cline { 4 - 5 } & 5 & 30.92 & 2.78 & pereals \\
\hline Małopolskie & 4 & 47.70 & 2.27 & 19.20 \\
Podkarpackie & $\mathbf{9}$ & $\mathbf{3 8 . 9 1}$ & $\mathbf{2 . 5 3}$ & $\mathbf{2 0 . 0 6}$ \\
Mean for mountain farms & $\mathbf{6}$ & 39.58 & 2.28 & 11.67 \\
Podlaskie & 4 & 52.61 & 3.06 & 16.65 \\
Kujawsko-pomorskie & 8 & 45.48 & 3.11 & 19.41 \\
Lubuskie & 6 & 33.63 & 2.82 & 18.85 \\
Mazowieckie & 5 & 44.95 & 3.06 & 15.31 \\
Pomorskie & 36 & $\mathbf{4 3 . 3 1}$ & $\mathbf{2 . 8 7}$ & $\mathbf{1 6 . 3 8}$ \\
Mean for lowland farms & 45 & $\mathbf{4 2 . 9 2}$ & $\mathbf{2 . 7 4}$ & $\mathbf{1 7 . 1 9}$ \\
Mean for studied farms & & & & \\
\hline
\end{tabular}


Table 2. The efficiency of area, fixed assets and employment in studied farms in the years 2007-2009 measured with the standard gross margin " 2008 " in $€$

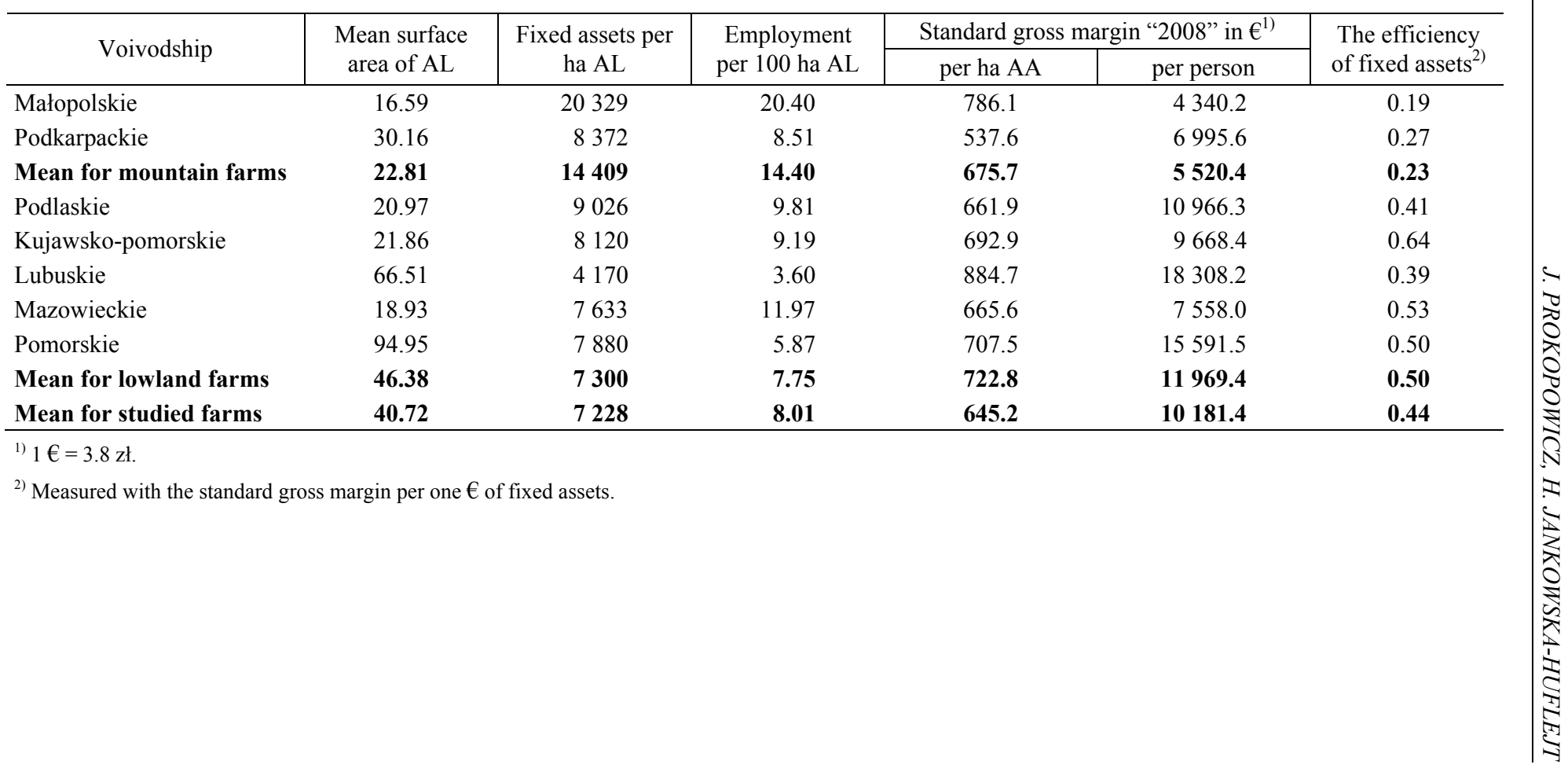


ECONOMIC EFFICIENCY OF STUDIED FARMS IN RELATION TO THE AREA OF AGRICULTURAL LANDS, THE VALUE OF FIXED ASSETS AND EMPLOYMENT

Mountain organic farms studied in the years 2007-2009 were characterised by a smaller area of AL (mean 22.81 ha) in comparison with the lowland farms (46.38 ha), by a higher value of fixed assets (14 $409 €$ per ha AL compared to $7300 €$ in lowland ones) and a higher employment per 100 ha AL (14.4 persons in mountain and 7.7 persons in lowland farms). At the same time mountain farms achieved lower standard gross margin "2008" both per ha AL (675.7 €) and per person $(5520.4 €)$ and lower efficiency of fixed assets measured as the value of standard gross margin per $1 €$ of fixed assets. Assuming the standard gross margin per ha Al, standard gross margin per person and the efficiency of fixed assets as 100 in mountain farms, the respective indices for lowland farms would be 107, 217 and 217. It thus appears that the economic efficiency of described productive factors is by $7 \%$ to $117 \%$ higher in lowland than in mountain farms (tab. 2). This is mainly the result of less favourable natural and economic conditions of farms situated in mountain regions (great differences in the elevation a.s.l., worse approach to fields, lower air and soil temperatures, shorter vegetation period). In general, one may conclude that both groups of organic farms were characterised by medium to low incomes from agricultural production, especially from plant production. In the years 2007-2009 the incomes were mainly generated by animal production - chiefly by dairy cows. The standard gross margin "2008" was medium to low both calculated per ha AL and per full time employed person. Mean value of the standard gross margin per ha decreased with the enlargement of farm area and increased when calculated per person.

Generally, the costs incurred for agricultural production in studied organic farms were not always compensated by the incomes from organic production. The incomes were enlarged by the EU subsidies which constituted on average c. $40.0 \%$ of the gross margin of farms and remained similar during the whole study period (JANKOWSKA-HUFLEJT and PROKOPOWICZ, 2011).

ECONOMIC RESULTS OF ORGANIC MOUNTAIN AND LOWLAND FARMS IN RELATION

TO THE AGE OF FARM OWNERS AND TO THE NUMBER AND MILK EFFICIENCY OF COWS IN A FARM

Economic results of organic farms (standard gross margin "2008") were analysed in relation to the age of farm owners and the number and milk efficiency of dairy cows in a farm. The importance (contribution) of Polish and European subsidies for the standard gross margin of farms (in \%) were also considered (tab. 3 ). 
Table 3. Standard gross margin " 2008 " and percentage share of subsidies in relation to the age of farm owners and the number and milk efficiency of cows in studied organic farms

\begin{tabular}{|c|c|c|c|c|c|c|}
\hline \multirow[t]{2}{*}{ Voivodship } & \multirow{2}{*}{$\begin{array}{l}\text { Farmer's } \\
\text { age }\end{array}$} & \multirow{2}{*}{$\begin{array}{c}\text { Number of } \\
\text { cows }\end{array}$} & \multirow{2}{*}{$\begin{array}{c}\text { Milk } \\
\text { efficiency } \\
\text { 1 per head }\end{array}$} & \multicolumn{2}{|c|}{$\begin{array}{c}\text { Standard gross margin } \\
\text { " } 2008 ", €\end{array}$} & \multirow{2}{*}{$\begin{array}{l}\text { \% of subsidies } \\
\text { in the standard } \\
\text { gross margin }\end{array}$} \\
\hline & & & & per ha AA & per person & \\
\hline Małopolskie & 44.6 & 3.3 & 3880 & 786.1 & 4340.2 & 61.5 \\
\hline Podkarpackie & 45.9 & 8.7 & 3612 & 537.6 & 6995.6 & 55.4 \\
\hline $\begin{array}{l}\text { Mean for mountain } \\
\text { farms }\end{array}$ & 45.9 & 6.0 & 3746 & 675.7 & 5520.4 & 58.4 \\
\hline Podlaskie & 43.4 & 12.4 & 2783 & 661.9 & 10966.3 & 42.1 \\
\hline Kujawsko-pomorskie & 47.2 & 13.0 & 4060 & 692.9 & 9668.4 & 30.8 \\
\hline Lubuskie & 44.3 & 12.5 & 3250 & 884.7 & 18308.2 & 20.0 \\
\hline Mazowieckie & 46.5 & 11.5 & 3489 & 665.6 & 7558.0 & 37.7 \\
\hline Pomorskie & 44.3 & 46.5 & 4155 & 707.5 & 15591.5 & 39.3 \\
\hline $\begin{array}{l}\text { Mean for lowland } \\
\text { farms }\end{array}$ & 45.4 & 21.1 & 3206 & 722.8 & 11969.4 & 34.0 \\
\hline $\begin{array}{l}\text { Mean for studied } \\
\text { farms }\end{array}$ & 45.7 & 15.4 & 3593 & 645.2 & 10181.4 & 41.0 \\
\hline
\end{tabular}

The owners of studied mountain farms were slightly older (45.9 years) than the owners of lowland farms (45.7 years). Moreover, mountain farms had fewer cows (6.0 on average) than lowland farms ( 21.10 heads) but showed a higher milk efficiency (3746 1 a head and 32061 a head, respectively). Mountain farms obtained lower standard gross margin per ha AL than lowland farms (675.7 $€$ and $722.8 €$, respectively or $107 \%$ in favour of lowland farms). Per capita value of this parameter was $5520.4 €$ in mountain farms and $11969.4 €$ in lowland farms i.e. by $17 \%$ more in the latter. The contribution of subsidies to standard gross margin "2008" was higher in mountain (58.4\%) than in lowland (34.0\%) farms. As already mentioned, this effect resulted from more favourable natural and economic conditions of the latter (small differences in altitude a.s.l., better access to fields, higher air and soil temperatures, longer vegetation period). Lower subsidies in lowland farms resulted from better natural and economic conditions (i.a. more favourable index of agricultural space valorisation). Moreover, standard gross margin "2008" in mountain farms was also affected by much higher employment in this group of farms.

From other studies (ProKOPOWICZ and JANKOWSKA-HuFLEJT, 2009) it appears, that the highest values of gross margin (both per person and per ha AL) were obtained in farms of milk efficiency between 4000 and 50001 a head. Fixed assets and employment had a limited but positive effect on the gross margin calculated per ha AL and negative effect when calculated per person and the efficiency of fixed assets. Together with increasing value of fixed assets and with increasing employment per ha AL the value of gross margin per ha AL increased and the same 
value per person employed in the farm - decreased. The efficiency of fixed assets decreased similarly and, moreover, was inversely proportional to milk efficiency. The increase of milk efficiency in a farm enforces additional investments in one stall for cows (the quality and value of buildings and facilities for feeding, milking and cooling the milk).

\section{COSTS OF FUEL, ELECTRIC ENERGY AND MANPOWER}

The analysis of mean costs calculated per 1 ha AL in both groups of studied farms showed (tab. 4) that in mountain farms the costs of fuel and manpower were lower than in lowland farms and that the costs of electric energy were similar in both groups. Assuming the cost in mountain farms as 100, the respective indices for lowland farms would be: fuel - 125, electric energy - 97, manpower - 155 . These figures reflect higher intensity of agricultural production in lowland farms.

Table 4. Mean cost of fuel, electric energy and hired labour in studied organic farms - the years 2007-2009

\begin{tabular}{|c|c|c|c|c|c|c|c|c|c|}
\hline \multirow{3}{*}{ Voivodship } & \multicolumn{9}{|c|}{ Mean cost, in $€$ per ha } \\
\hline & \multicolumn{3}{|c|}{ fuel (liquid and solid) } & \multicolumn{3}{|c|}{ electric energy } & \multicolumn{3}{|c|}{ hired labour } \\
\hline & mean & $\min$. & $\max$. & mean & $\min$. & $\max$. & mean & $\min$. & $\max$. \\
\hline Małopolskie & 94 & 30 & 146 & 40 & 16 & 73 & 21 & 4 & 56 \\
\hline Podkarpackie & 49 & 24 & 75 & 25 & 12 & 49 & 19 & 4 & 48 \\
\hline $\begin{array}{l}\text { Mean for mountain } \\
\text { farms }\end{array}$ & 72 & 27 & 111 & 33 & 14 & 61 & 20 & 4 & 52 \\
\hline Podlaskie & 72 & 29 & 111 & 33 & 14 & 61 & 20 & 4 & 52 \\
\hline Kujawsko-pomorskie & 64 & 64 & 99 & 30 & 13 & 57 & 20 & 4 & 51 \\
\hline Lubuskie & 78 & 16 & 198 & 14 & 3 & 43 & 30 & 16 & 52 \\
\hline Mazowieckie & 71 & 36 & 136 & 25 & 10 & 53 & 23 & 8 & 52 \\
\hline Pomorskie & 101 & 55 & 154 & 41 & 8 & 77 & 64 & 3 & 279 \\
\hline Mean for lowland farms & 90 & 44 & 157 & 32 & 12 & 66 & 31 & 10 & 101 \\
\hline Mean for studied farms & 85 & 39 & 144 & 32 & 12 & 65 & 28 & 8 & 87 \\
\hline
\end{tabular}

Despite large demand for manpower to control weeds and protect plants, the studied farms used hired labour to a small extent which means that their own manpower was sufficient.

Other studies (PROKOPOWICZ and JANKOWSKA-HUFLEJT, 2007; 2008; 2009; JANKOWSKA-HUFLEJT and PROKOPOWICZ, 2011) pointed to a distinct positive correlation between the costs and milk efficiency in studied farms. The costs of fuel (liquid and solid), electric energy and hired labour increased with increasing milk efficiency. 


\section{STANDARD GROSS MARGINS IN MOUNTAIN AND LOWLAND FARMS}

- THE YEARS “2005”- “2008”

The analysis of standard gross margins per ha AL (tab. 5) shows a moderately increasing trend. Mean gross margin from the four study periods was $708.7 €$ per ha $\mathrm{AL}$ and ranged from $487.3 €$ in podkarpackie voivodship to $833.6 €$ in lubuskie voivodship. In general, the least favourable were the indices for the year "2005" and those for the remaining years were similar to each other (PROKOPOWICZ and JANKOWSKA-HUFLEJT, 2007; 2008; 2009). Based on the evaluation of standard gross margins, one may conclude that lowland farms obtained slightly better economic results than the mountain ones. It means that agricultural space is utilised more effectively in lowland farms. Assuming 100 as the value of standard gross margin per ha AL in mountain farms, the respective values for lowland farms would achieve: 111 in the year "2005", 128 in the year "2006", 137 in the year "2007" and 114 in the year "2008" (mean 121). It thus appears that standard gross margin in the study years was higher by $11-37 \%$ in lowland than in mountain farms.

Slightly different were the proportions when standard gross margin was calculated per full-time employed person in a farm. The gross margin so calculated (tab. 5) showed a moderately increasing trend. Its mean value from the four three-yearlong periods was $8007.1 €$ with the range from $4347.3 €$ in małopolskie voivodship to $14617.6 €$ in lubuskie voivodship. In general, the least favourable was the index for the year "2005" and the indices for the remaining years were similar to each other. Studied lowland farms obtained better indices of the gross margin per person compared with mountain farms. If the index for mountain farms were 100 than the respective values for lowland farms would be: 182 for the period " 2005 ", 195 for "2006", 226 for "2007" and 223 for "2008" (mean 208). It means that the studied lowland farms, despite lower subsidies, obtained the standard gross margin higher by $82 \%$ to $126 \%$ compared with mountain farms. Organic lowland farms exploited their manpower resources more effectively, mainly because of better natural and economic conditions and smaller employment.

Performed economic analysis showed that not all meadow organic farms had a chance of further development and investment. Acc. to JÓZWIAK (2008) such a chance have farms of an economic size above 10 500-13 $000 €$, which pertains to c. $69 \%$ of studied farms (PROKOPOWICZ and JANKOWSKA-HUFLEJT, 2009), while $31 \%$ of smaller farms will not accomplish necessary (acc. to Kodeks... (2002)) investments like individual sewage treatment plants, slurry tanks or silos.

Economic results of organic farms may increase with increasing incomes of large part of the country population and with the improvement of the purchase of organic products. These processes may temporarily be disturbed by the existing economic crisis. 
Table 5. Standard gross margin in studied organic farms - the years 2005-2008

\begin{tabular}{|c|c|c|c|c|c|c|c|c|c|c|}
\hline \multirow{3}{*}{ Voivodship } & \multicolumn{10}{|c|}{ Standard gross margin } \\
\hline & \multicolumn{2}{|c|}{ "2005" } & \multicolumn{2}{|c|}{ "2006" } & \multicolumn{2}{|c|}{ "2007" } & \multicolumn{2}{|c|}{ "2008" } & \multicolumn{2}{|c|}{ mean } \\
\hline & $€$ per ha & $€$ per person & $€$ per ha & $€$ per person & $€$ per ha & $€$ per person & $€$ per ha & $€$ per person & $€$ per ha & $€$ per person \\
\hline Małopolskie & 843.0 & 3999.5 & 800.2 & 4561.1 & 732.9 & 4488.5 & 786.1 & 4340.2 & 740.5 & 4347.3 \\
\hline Podkarpackie & 378.5 & 5286.1 & 519.8 & 7295.3 & 513.1 & 7431.1 & 537.6 & 6995.6 & 487.3 & 6752.1 \\
\hline $\begin{array}{l}\text { Mean for mountain } \\
\text { farms }\end{array}$ & 525.4 & 4571.3 & 675.6 & 5776.3 & 635.2 & 5796.4 & 675.7 & 5520.4 & 628.0 & 5416.1 \\
\hline Podlaskie & 772.0 & 8858.1 & 984.9 & 11364.6 & 757.1 & 10936.1 & 661.9 & 10966.3 & 794.0 & 10531.3 \\
\hline Kujawsko-pomorskie & 475.2 & 6131.8 & 658.8 & 78810.8 & 7755.9 & 9186.1 & 692.9 & 9668.4 & 645.7 & 8217.0 \\
\hline Lubuskie & 424.3 & 9180.7 & 943.8 & 13739.2 & 1082.5 & 17243.2 & 884.7 & 18308.2 & 833.6 & 14617.6 \\
\hline Mazowieckie & 685.1 & 6375.4 & 844.9 & 7609.8 & 882.8 & 4533.8 & 665.6 & 4558.0 & 754.6 & 7269.2 \\
\hline Pomorskie & 573.5 & 10347.3 & 780.6 & 14314.1 & 881.4 & 15871.7 & 707.5 & 15591.5 & 735.7 & 14031.1 \\
\hline Mean for lowland farms & 582.9 & 8314.2 & 864.4 & 11271.0 & 871.1 & 13076.8 & 772.8 & 12326.1 & 760.3 & 11247.0 \\
\hline Mean for studied farms & 586.8 & 6178.6 & 800.5 & 8929.0 & 802.3 & 10213.6 & 645.2 & 9907.2 & 708.7 & 8807.1 \\
\hline
\end{tabular}




\section{CONCLUSIONS}

1. Economic efficiency of the use of land and labour resources in organic meadow farms measured with the standard gross margin per ha AL and per fulltime employed person was better in lowland than in mountain farms despite higher subsidies in the latter. The efficiency calculated per ha AL decreased while that calculated per person - increased with increasing surface area of AL. The costs of agricultural production were not always satisfactorily compensated by incomes from organic production.

2. The owners of studied mountain farms were slightly older than the owners of lowland farms, kept fewer cows (6.0 heads) than those in lowland farms $(21.10$ heads) and obtained higher milk efficiency (3746 1 a head versus 32061 a head in lowland farms). Standard gross margin "2008" per ha AL was lower in mountain than in lowland farms (675.7 and $722.8 €$, respectively or $107 \%$ in favour of lowland farms). The same parameter calculated per person amounted $5520.4 €$ in mountain farms and $11969.4 €$ in lowland farms i.e. by $117 \%$ more.

3. The standard gross margin (per ha AL and per person) in most farms of both groups showed a slightly increasing tendency during the study period which means that the efficiency of land use and labour slowly increased.

4. Economic analysis showed that not all studied meadow farms had a chance of further investment and development. Such prospects had c. $69.0 \%$ of studied farms.

5. Subsidies from the state budget and from the EU are an important factor affecting economic efficiency of organic farms. They increased the income of studied farms and, on average, constituted $41.0 \%$ of standard gross margin ranging from $43.0 \%$ in lowland to $58.4 \%$ in mountain farms. Performed studies showed that the production of healthy food in organic farms is possible providing a definite level of Polish and European subsidies.

\section{REFERENCES}

1. Badania nad wpływem pasz pochodzenia łąkowo-pastwiskowego na produkcję zwierzęcą w gospodarstwach ekologicznych, 2005, 2006, 2007, 2008, 2009. (Studies on the effect of grassland fodder on livestock production in organic farms, 2005, 2006, 2007, 2008, 2009). Raport naukowy z realizacji projektu badawczego zleconego przez MRiRW, kierowanego przez dr inż. H. Jankowską-Huflejt.

2. JANKOWSKa-HufleJT H., PROKOPOwicz J., 2011. Uwarunkowania i czynniki rozwoju produkcji w łąkarskich gospodarstwach ekologicznych ze szczególnym uwzględnieniem subwencji. (Determinants and factors of the development of production in meadow organic farms with special reference to subsidies). Woda Środowisko Obszary Wiejskie 11, 1 (33): 113-124.

3. Jankowska-Huflejt H., Zastawny J., WróBel B., Burs W., 2004. Przyrodnicze i ekonomiczne uwarunkowania rozwoju łąkarskich gospodarstw ekologicznych w Polsce. (Natural and economic determinants of the development of grassland-based organic farms in Poland). W: Perspektywy go- 
spodarowania na trwałych użytkach zielonych w ramach „Wspólnej Polityki Rolnej UE”. Materiały Seminaryjne, 49, Falenty, IMUZ: 37-50.

4. JÓZWIAK W., 2008. Możliwości inwestycyjne polskich gospodarstw rolnych na obszarach OSN. (Investment possibilities of Polish farms in the LFA). Woda Środowisko Obszary Wiejskie, 8 $2 b(24): 51-60$.

5. Kodeks dobrej praktyki rolniczej, 2002. (The code of good agricultural practices). Warszawa, MRiRW, MŚ: 1-93.

6. Metodyka liczenia nadwyżki bezpośredniej i zasady typologii gospodarstw rolniczych (według standardów Unii Europejskiej), 2000. (Methods of calculating gross margin and the principles of farm typology according to the standards of the EU). Warszawa, FAPA: 1-55.

7. PROKOPOWICZ J., JANKOWSKA-HuFleJT H., 2007. Opłacalność produkcji w łąkarskich gospodarstwach ekologicznych w latach 2004-2006. (Production profitability in grassland-based organic farms in the years 2004-2006). Journal of Research and Applications in Agricultural Engineering, 52 (4): 32-37.

8. Prokopowicz J., JANKowsKa-Huflejt H., 2008. Ocena ekonomiczna kierunków działalności gospodarstw ekologicznych, mierzona standardową nadwyżką bezpośrednią „2006”. (). Journal of Research and Applications in Agricultural Engineering, 53 (4): 45-50.

9. PROKOPOWICZ J., JANKOWSKA-HufleJT H., 2009. Ocena ekonomiczna badanych gospodarstw ekologicznych, w latach 2004-2008, z uwzględnieniem subwencji UE. (Economic assessment of organic farms studied in the years 2004-2008 with the consideration of the EU subsidies). Journal of Research and Applications in Agricultural Engineering, 54 (4): 55-62.

10. Rolnictwo ekologiczne w Polsce - raport 2007-2008, 2009. (Organic farming in Poland - reports 2007-2008, 2009). http://www.ijhar-s.gov.pl/pliki/download/RAPORT2007-2008 (27.03. 2010).

11. Źródłowe dane ankietowe, 2004, 2005, 2006, 2007, 2008, 2009. Wypełnione ankiety badanych gospodarstw ekologicznych. (Source data 2004, 2005, 2006, 2007, 2008, 2009. Questionnaires of studied organic farms).

\section{STRESZCZENIE}

\section{Produkcyjne i ekonomiczne czynniki rozwoju górskich ląkarskich gospodarstw ekologicznych w latach 2004-2009}

Słowa kluczowe: takarskie gospodarstwa ekologiczne, dotacje, pogłowie, standardowa nadwyżka bezpośrednia, struktura zasiewów, zatrudnienie

Badania, metodą wywiadu kierowanego, przeprowadzono w latach 20042009, w ekologicznych łąkarskich gospodarstwach rolnych -9 na terenie 2 województw górskich (małopolskie i podkarpackie) oraz 32 na terenie 7 województw nizinnych (kujawsko-pomorskie, lubuskie, mazowieckie, podlaskie, pomorskie, warmińsko-mazurskie, wielkopolskie). Obszar użytków rolnych (UR) w obu grupach gospodarstw wyniósł w 2009 r. 1891,74 ha, w poszczególnych gospodarstwach wahał się od 3,01 ha do 305,80 ha, średnio 46,14 ha. Na tle charakterystyki przyrodniczo-rolniczej i ekonomicznej przedstawiono wyniki produkcyjne (plony w t $\cdot h a^{-1}$, obsada zwierząt w SD $h^{-1}$ UR) i ekonomiczne (standardowa nadwyżka bezpośrednia $\mathrm{w}$ euro/ha UR i na osobę w pełni zatrudniona) omawianych grup gospodarstw. Postawiono hipotezę że w ekologicznych łąkarskich gospodarstwach 
górskich możliwa jest produkcja zdrowej żywności dopuszczalna przyrodniczo (ekologicznie), akceptowana społecznie i efektywna ekonomicznie.

Badano następujące czynniki: obszar UR w ha, obsadę krów w szt., mleczność krów w 1, wiek właścicieli gospodarstw w latach, wartość środków trwałych $\mathrm{w} \mathrm{z} \cdot \mathrm{ha}^{-1}$ UR. Badania wykazały, że w obu badanych grupach łąkarskich gospodarstw ekologicznych (górskich i nizinnych) możliwa jest efektywna ekonomicznie produkcja ,jakościowej żywności” - pod warunkiem określonego poziomu dopłat. Wyniki ekonomiczne gospodarstw ekologicznych mogą wzrastać wraz ze wzrostem dochodów większej liczby ludności naszego kraju, oraz z poprawą organizacji skupu rolniczej produkcji ekologicznej, szczególnie w zachodnich rejonach naszego kraju, ze względu na możliwość jej eksportu do Europy Zachodniej. Przejściowo, w wyniku obecnego kryzysu ekonomicznego, popyt na żywność ekologiczną, z powodu wyższych cen, może być nieco zmniejszony. 